Гордана Ј. Ђоковић*

Универзитет у Београду

Филолошки факултет https://doi.org/10.18485/analiff.2020.32.2.23

001.3:050.486

Stručni rad

Primljen: 22.06.2019

Prihvaćen: 19.10.2019

\title{
НАУЧНИ ЧАСОПИСИ ФИЛОЛОШКОГ ФАКУЛТЕТА: ВИДЉИВОСТ, ЦИТИРАНОСТ, ВРЕДНОВАЊЕ ${ }^{1}$
}

Научно-истраживачки резултати и њихов квалитет мере се путем међународне видљивости научних часописа у којима су публиковани. Већа видљивост научно-истраживачких резултата доводи до пораста цитирања. Мерење цитираности представља један од најважнијих критеријума у мерењу квалитета научника, часописа, факултета и универзитета. Укључивање у најзначајније и најпрестижније електронске цитатне базе података представља императив за уредништва савремених научних часописа. Филолошки факултет Универзитета у Београду има веома богату издавачку продукцију научних часописа. У раду ће бити дат преглед наслова научних часописа у издању Филолошког факултета, мере које доводе до повећања видљивости на глобалном нивоу као и анализа њихове заступљености у електронским базама података.

Кључне речи: Филолошки факултета Универзитета у Београду, научно-истраживачки резултати, видљивост, цитираност, цитатне базе података.

\section{Увод}

Научни часопис је периодична публикација у којој се објављују резултати најновијих истраживања у циљу унапређења науке. Периодичне публикације излазе повремено у краћим или дужим временским размацима, са истим насловом, нумерисане редним бројем и датумом а настале су како би информисале јавност о некој тематици. Историја научне периодике започела је 1665. године појавом часописа Journal de Scavans у Паризу и Philosophical transactions у Лондону и отада

\footnotetext{
* gordana.djokovic@fil.bg.ac.rs

1 Рад је изложен на Међународној научној конференцији Дигитална хуманистика и словенско културно наслеђе, Филолошки факултет Универзитета у Београду, 6-7. мај 2019.
} 
Гордана Ј. Ђоковић

се њихов број свакодневно повећавао. Већина научних часописа је специјализована за одређено подручје науке и на својим страницама објављује најновија истраживања и резултате из подручја које часопис покрива. То потврђује и чињеница да су научни часописи највише тражени у научним круговима и зато чине већину фондова специјалних библиотека. „Актуелност информација у периодичним публикацијама је већа од оних у монографским, ради чега је научна периодика значајан чинилац фондова специјалних библиотека.”(Вранеш, Марковић, 2013: 245)

Развојем Интернета променило се и издавање периодичних публикација. Велики број светских научних часописа, поред папирне, објављује и своју електронску форму. Није редак ни случај да се папирна форма заобиђе и да се објављује само електронска форма часописа. Нагли пораст броја електронских часописа најлакше се може пратити преко ISSN Online, светске базе за периодичне публикације. Међународни стандардни број за серијске публикације - ISSN, додељује се свим серијским публикацијама, односно оним које излазе континуирано у одређеном временском периоду (новине, часописи, годишњаци, монографске серије, директоријуми), било да су у штампаном или електронском облику. ISSN омогућује идентификацију и контролу свих серијских публикација објављених како на националном, тако и на интернационалном нивоу. У бази се налазе записи о серијским публикацијама објављеним на различитим медијима: папир, микрофилм, микрофиш, ЦД-ром, компјутерске магнетне траке, дискете, звучне и видео публикације, публикације објављене Брајевом азбуком, онлине публикације. Убрзан развој електронских публикација одразио се и на ISSN Online базу јер се у њу свакодневно укључује све већи број електронских серијских публикација. Тренутно се у бази налази преко 2,5 милиона наслова серијских публикација које су доступне преко Интернета; годишње се додаје око 130000 нових наслова ${ }^{2}$. У бази се уз наслове часописа налазе и додатни линкови којима је омогућен или увид у пуне текстове или основне информације о часопису што додатно повећава његову доступност и видљивост а самим тим повећавају се и могућности да објављени радови буду више цитирани.

2 International Standard Serial Number.

Доступно преко https://www.issn.org/ [3.10.2020] 
НАУЧНИ ЧАСОПИСИ ФИЛОЛОШКОГ ФАКУЛТЕТА ...

\section{Doi.Fil}

Повећању видљивости доприноси и DOI ознака која представља јединствену алфанумеричку ниску која се додељује појединачном објекту (чланку, раду у зборнику, монографији, поглављу у монографији) у дигиталном облику, и повезује корисника са дигиталном верзијом документа на интернету. DOI ознака се састоји од алфанумеричког низа састављеног из два неједнака дела - префикса и суфикса. Префикс је стални број који CrossRef агенција додељује заинтересованим издавачима, док суфикс за своје публикације додељују издавачи који потом CrossRef агенцији шаљу основне библиографске информације-метаподатке (аутор, наслов, година издања, ISSN, ISBN, DOI и адресу приступне странице на интернету). Одржавање приступне странице на интернету је у обавези издавача који је дужан да сваку промену у адреси пријави CrossRef агенцији која одржава базу информација о регистрованим документима.

DOI бројеве може додељивати издавач или нека већа институција која додељује DOI бројеве за већи број наслова научних часописа. Филолошки факултет Универзитета у Београду додељује DOI бројеве и одржава приступне странице часописа од 2016. године и по броју додељених бројева се налази на трећем месту у Србији, после Народне библиотеке Србије и Српског цитатног индекса (SCIndex). Ове три установе нису једине у Србији које региструју DOI бројеве, то чини још двадесетак мањих издавача искључиво за потребе сопствене издавачке прокукције.

Иницијатива за приступање CrossRef агенцији и покретање активности везаних за додељивање DOI бројева, обраду метаподатака и израду приступних страница, кренула је са Катедре за библиотекарство и информатику Филолошког факултета Универзитета у Београду у току 2014. године. Извршене су анализе издавачке продукције Филолошког факултета и направљен план рада. Сарадња ca CrossRef агенцијијом започета је крајем 2015. године, док су први резултати били видљиви почетком 2016. године. Због велике издавачке продукције зборника радова са међународних и националних конференција, одлучено је да се поред чланака из часописа крене и са додељивањем бројева за чланке у зборницима радова и по томе је Филолошки факултет јединствен у нашој земљи. Остале институције које су оствариле сарадњу са CrossRef агенцијом, додељују бројеве искључиво 
Гордана Ј. Ђоковић

за чланке у научним часописима. Временом су се издањима Филолошког факултета прикључила и издања часописа и зборника радова других, мањих издавача који су остварили сарадњу са Филолошким факултетом. Данас је у бази Doi.Fil доступно 33 наслова научних часописа (неки са великим бројем годишта) и 69 наслова зборника радова ${ }^{3}$. Од 33 наслова научних часописа, чак 13 наслова су у издању Филолошког факултета.

Електронска форма и DOI ознака представљају предуслов за укључивање часописа у електронске библиографске и цитатне базе података, најпознатије међу њима Web of Science Core Collection i Scopus. Мање познате и мање признате базе су Google Scholar i Erih plus. Овај задатак представља императив уредништвима научних часописа у свим земљама света. Објављивање у угледним часописима, реферисаним у водећим библиографским и цитатним базама података, доприноси напредовању појединца (универзитетског професора), али такође утиче и на углед факултета и универзитета. Европски пројекти којима се данас, у великој мери, финансирају научна истраживања у бројним областима, рангирање и вредновање пројеката врше на основу објављених резултата у угледним часописима (Macan, Petrak, 2015: 37).

Научни часописи се уређују према светски признатим стандардима и пријављују за реферисање у престижним базама података. Високо рангираним и квалитетнијим часописима сматрају се они часописи који имају „компетентно и посвећено уредништво, високе критеријуме за одабир рукописа, квалитетно рецензирање и врхунско техничко обликовање радова, сагласно међународним стандардима““(Шипка, 2014: 11). Утицајне библиографске базе података, попут базе Web of Science Core Collection ${ }^{4}$, намећу озбиљне формалне критеријуме који се односе на техничко уређивање чланака. Сваки чланак мора бити опремљен основним метаподацима неопходним за опис чланка (наслов рада на језику рада и страном језику, апстракт рада на језику рада и страном језику, кључне речи на језику рада и страном језику), уредничка класификација рада, ознака пројекта, ауторска афилијација, датум пријема и прихватања рада, јавно доступан списак свих рецензената, DOI ознаке, online рецензирање и праћење рецензија.

3 doi.Fil/Filološki fakultet, Univerzitet u Beogradu.

Доступно преко http://doi.fil.bg.ac.rs [1.10.2020]

4 Web of Science Core Collection - у наставку текста WoS 


\section{Библиометријска анализа у Србији}

Високи критеријуми наметнути од стране WoS-a, примењују се и код домаће категоризације часописа. Вредновање домаћих научних часописа се у Србији спроводи од 2003. године и финансира се средствима Министарства просвете, науке и технолошког развоја. Почевши од 2016. године, евалуацију и израду библиометријских извештаја домаћег научног издаваштва врши Математички институт САНУ. Пре тога библиометријске извештаје је израђивао Центар за евалуацију у образовању и науци (ЦЕОН). Библиометиријски извешитаји о научним часойисима из Рейублике Србије које израђује Математички институт САНУ доступни су за 2016, 2017. и 2018. годину преко интернет адреce http://bibliometrija.mi.sanu.ac.rs искључиво са академског IP домена у Србији. Индикатори на које се у библиометријским извештајима обраћа пажња дати су у примеру библиометријског извештаја за часопис Анали Филолошког̄ факулиетей за 2018. годину (табела 1). Наведени индикатори намењени су уредништвима часописа и имају за циљ да укажу на одређене недостатке у уређивању који могу бити техничке али и садржинске природе и служе као путоказ у даљој уређивачкој политици и унапређивању квалитета часописа.

Табела 1: Библиометријски извештај математичког института САНУ за часопис Анали Филолошкой факулиеет̄а за 2018. годину5.

\section{Anali Filološkog fakulteta ISSN 0522-8468}

Opremljenost:

Apstrakt: Ima

Ključne reči: Ima

Afilijacija autora: Ima

E-mail autora: Ima

Tip rada: Ima

DOI: Ima

Datum prijema i prihvatanja: Ima

Zahvalnica (projekat): Ima

Uputstvo autorima: Ima

Dostupnost putem interneta: Da

5 Bibliometrijski izveštaj o naučnim časopisima iz Republike Srbije http://bibliometrija.mi.sanu.ac.rs (приступ 23.9.2020.) 
Гордана Ј. Ђоковић

Ukupan broj radova: 29

Procenat radova na stranim jezicima

(engleski, francuski, nemački, ruski, italijanski, španski):

engleski: $\mathbf{2 1 \%}$

Procenat radova stranih autora: $10 \%$

Ukupan broj referenci: $\mathbf{7 1 0}$

Procenat radova sa referencama: $\mathbf{1 0 0 \%}$

Prosečan broj referenci po radu (isključujući radove bez referenci): 18

Tip referenci:

Naučni časopisi: $16 \%$

Monografije: $63 \%$

Poglavlja u monografijama i tematskim zbornicima: $\mathbf{1 3 \%}$

Zbornici sa konferencija: $\mathbf{1 \%}$

Doktorati: 1\%

Magistarski i master radovi: $\mathbf{0 \%}$

Ostalo: $\mathbf{5 \%}$

Prosečna starost referenci: $\mathbf{1 5}$ god.

Библиометријски извештај о часописима, израђује се за потребе категоризације и рангирања научних часописа који излазе у Србији и врше се на основу електронске верзије часописа које издавачи достављају у Дийииални рейозийоријум Нарояне библиоиеке Србије. У циљу унапређења квалитета домаћих часописа и њиховог потпунијег укључивања у међународни систем размене научних информација, 2005. године је донет Акй о уређивању научних часойиса. „Актом се посебно уређује опремање часописа у целини и чланка као његовог саставног дела. Такође се утврђује садржај документације која се користи у уређивачком раду."6

На основу библиометријских извештаја о часописима које израђује Математички институт САНУ, Министар на предлог надлежних Матичних научних одбора доноси коначну одлуку о категоризацији домаћих часописа која се једном годишње објављује на интернет страници Министартва просвете, науке и технолошког развоја. Надлежни Матични научни одбори имају могућност да часописима

6 Акт о уређивању научних часописа („Службени гласник Републике Србије“, бр 79/05)

7 Министраство просвете, науке и технолошког развоја/категоризација часописа . Доступно http://www.mpn.gov.rs/casopisi/ [приступ 22.9.2020.] 
доделе једну од пет могућих категорија. Највиша категорија је M24 - национални часопис међународног значаја, затим следе категорије M51 - врхунски часопис националног значаја; M52 - истакнути национални часопис; M53 - национални часопис и M54 - новопокренути научни часопис. Категоризација, односно вредновање часописа врши се на основу Библиометријског извештаја о часописима Математичког института САНУ. ${ }^{8}$

Часописи које самостало или као суиздавач издаје Филолошки факултет Универзитета у Београду рангирани су у научној области Срйски језик и књижевности. Према категоризацији часописа из 2019. године рангирани су у табели према категоријама приказаним у табели 2.

Табела 2: Извод из категоризације домаћих часописа у категорији српски језик и књижевност чији је издавач или суиздавач Филолошки факултет Универзитета у Београду

\begin{tabular}{|c|c|c|c|}
\hline Назив часописа & ISSN & Издавач/и & Категорија \\
\hline  & $0350-6673$ & $\begin{array}{l}\text { Филолошки факултет } \\
\text { Универзитета у Београду }\end{array}$ & M24 \\
\hline 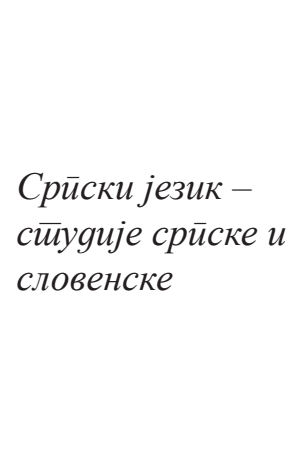 & $0354-9259$ & $\begin{array}{l}\text { Научно друштво за } \\
\text { неговање и проучавање } \\
\text { српскогјезика, } \\
\text { Филолошки факултет } \\
\text { Универзитета у Београду, } \\
\text { Филолошки факултет } \\
\text { Никшић, Филолошки } \\
\text { факултет Бања Лука и } \\
\text { Филолошки факултет } \\
\text { Српско Сарајево }\end{array}$ & M24 \\
\hline 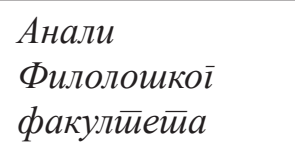 & $0522-8468$ & $\begin{array}{l}\text { Филолошки факултет } \\
\text { Универзитета у Београду }\end{array}$ & M51 \\
\hline
\end{tabular}

8 Bibliometrijski izveštaj o naučnim časopisima iz Republike Srbije http://bibliometrija.mi.sanu.ac.rs (приступ 25.9.2020.) 
Гордана Ј. Ђоковић

\begin{tabular}{|c|c|c|c|}
\hline 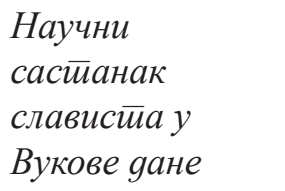 & 0351-9066 & $\begin{array}{l}\text { Међународни } \\
\text { славистички центар и } \\
\text { Филолошки факултет } \\
\text { Универзитета у Београду }\end{array}$ & M51 \\
\hline $\begin{array}{l}\text { Филолошки } \\
\text { ирейлеg }\end{array}$ & 0015-1807 & $\begin{array}{l}\text { Филолошки факултет } \\
\text { Универзитета у Београду }\end{array}$ & M51 \\
\hline $\begin{array}{l}\text { Книжевности и } \\
\text { језик }\end{array}$ & 0454-0689 & $\begin{array}{l}\text { Филолошки факултет, } \\
\text { Друштво за српски језик } \\
\text { и књижевност Србије }\end{array}$ & M51 \\
\hline Слависииика & $1450-5061$ & $\begin{array}{l}\text { Филолошки факултет, } \\
\text { Славистичко друштво } \\
\text { Србије }\end{array}$ & M51 \\
\hline $\begin{array}{l}\text { Belgrade:English } \\
\text { Language\& } \\
\text { Literature } \\
\text { Studies }\end{array}$ & 1821-3138 & $\begin{array}{l}\text { Филолошки факултет } \\
\text { Универзитета у Београду }\end{array}$ & M52 \\
\hline 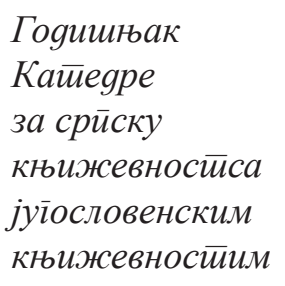 & $1820-5305$ & $\begin{array}{l}\text { Филолошки факултет } \\
\text { Универзитета у Београду }\end{array}$ & M52 \\
\hline Книженстиво & 2217-7809 & $\begin{array}{l}\text { Филолошки факултет } \\
\text { Универзитета у Београду }\end{array}$ & M52 \\
\hline $\begin{array}{l}\text { Применена } \\
\text { линівисиичка }\end{array}$ & & $\begin{array}{l}\text { Друштво за примењену } \\
\text { лингвистику Србије, } \\
\text { Филолошки факултет } \\
\text { Универзитета у Београду, } \\
\text { Филозофски факултет } \\
\text { Универзитета у Новом } \\
\text { Саду }\end{array}$ & M52 \\
\hline $\begin{array}{l}\text { Italica } \\
\text { Belgradensia }\end{array}$ & 0353-4766 & $\begin{array}{l}\text { Филолошки факултет } \\
\text { Универзитета у Београду }\end{array}$ & M53 \\
\hline
\end{tabular}


НАУЧНИ ЧАСОПИСИ ФИЛОЛОШКОГ ФАКУЛТЕТА ...

\begin{tabular}{|c|c|c|c|}
\hline  & 2217-2181 & $\begin{array}{l}\text { Филолошки факултет } \\
\text { Универзитета у Београду }\end{array}$ & M53 \\
\hline $\begin{array}{l}\text { Живи језищи } \\
: \text { часойис за } \\
\text { сйране језике и } \\
\text { кьижевностии }\end{array}$ & 0514-7743 & $\begin{array}{l}\text { Филолошки факултет } \\
\text { Универзитета у Београду }\end{array}$ & M53 \\
\hline Словеника & $2466-555 X$ & $\begin{array}{l}\text { Филолошки факултет } \\
\text { Универзитета у Београду }\end{array}$ & M53 \\
\hline  & 2560-4414 & $\begin{array}{l}\text { Филолошки факултет } \\
\text { Универзитета у Београду }\end{array}$ & M54 \\
\hline
\end{tabular}

\section{Цитираност и цитатни индекси}

Научно-истраживачки резултати и њихов квалитет мере се путем међународне видљивости научних часописа у којима су публиковани. Већа видљивост научно-истраживачких резултата доводи до пораста цитирања. Мерење цитираности представља један од најважнијих критеријума у мерењу квалитета научника, часописа, факултета и универзитета. Укључивање у најзначајније и најпрестижније електронске цитатне базе података представља императив за уредништва савремених научних часописа. WoS и Scopus важе за две најугледније и најутицајније комерцијалне цитатне базе података чије се цитатне анализе и библиометријски показатељи користе за вредновање научних часописа у целом свету.

Web of Science (WoS) представља најстарију базу података научне литературе и најутицајнију цитатну базу података која реферише само $10-12 \%$ светских научних часописа који су одабрани строгом селекцијом. Састоји се од шест база података:

- SCI (Science Citation Index) - покрива област природних наука.

- SSCI (Social Science Citation Index) - покрива обаст друштвених наука.

- AHCI (Art and Humanities Citation Index) - покрива област уметности и хуманистичких наука. 
Гордана Ј. Ђоковић

- ESCI (Emerging Sources Citation Index) - укључује наслове часописа чији је процес евалуације у току.

- Book Citation Index - укључује књиге,

- Conference Proceedings Citation Index - укључује зборнике радова са конференција.

Часойис Italica Belgradensia се од јуна месеца 2019. године индексира у бази ESCI (Emerging Sources Citation Index) и у току је процес евалуације. У овој бази процес евалуације тренутно чека 40 часописа из Србије и само један у издању Филолошког факултета (Italica Belgradensia).

Journal Citation Report - JCR у оквиру WoS-a је база часописа која се формира по дисциплинама на основу вредности импакт фактора-IF, или фактора утицајности часописа. IF се израчунава тако што се број цитата за последње две године подели са бројем објављених радова у те две године и сматра се библиометријским индикатором научних часописа који се реферишу у WoS-y. Собзиром на чињеницу да се импакт фактор часописа објављује у $J C R$ у јуну месецу сваке године на основу пресека броја цитата који се прави у марту месецу, и да је неопходно да часопис буде реферисан у WoS-y минимум две године, онда је за очекивати да би часопис Italica Belgradensia могао да добије свој први импакт фактор у јуну 2022. године.

База SCOPUS је производ угледног издавача научне литератуpe Elsevier, покренута је 2004. године са циљем да окупи већи број научних часописа од WoS-a будући да су критеријуми за њихово укључивање нешто блажи. У Scopus-у се индексира знатно већи број европских часописа него y WoS-y па је тако већи и број наслова научних часописа из наше земље. Према подацима који се објављзју на КОБСОН страници ${ }^{9}$, тренутно се у Scopus-у индексира 91 часопис из Србије али ниједан часопис у издању Филолошког факултета Универзитета у Београду. Једини часопис из области филологије који се индексира у Scopus бази је часопис Komunikacija i kultura Online. Часопис излази у електронском облику једном годишње од 2010. године и DOI бројеве региструје преко Филолошког факултета. Од 2018. године индексира се у Scopus-y. Библиометријски индикатор који се користи у цитатној бази Scopus назива се SCImago Journal Rank (SJR)

9 Kobson/Referisani časopisi. Доступно:

https://kobson.nb.rs/nauka_u_srbiji/referisani_casopisi.23.html [3.10.2020]. 
и објављује се на страници SCImago Journal \& Country Rank ${ }^{10}$. SJR ce израчунава на основу цитата објављених научних радова, при чему се рачунају цитати које је неки часопис добио у текућој години за радове који су објављени у претходне три године и изражавају се $\mathrm{h}$ индексом. На основу SJR, индексирани часописи се сврставају у четири категорије (Q1-Q4), при чему је Q4 почетна категорија и добијају је часописи који су тек почели да се индексирају у Scopus-y и самим тим немају довољан број остварених цитата. Домаћи важећи Правилник ${ }^{11}$, препознаје само категорије Q1, Q2 и Q3 из SJR, па тако часописимима Q1 додељује категорију M23, док часописима Q2 и Q3 додељује категорију М24 ${ }^{12}$.

Google Scholar je још једна база научне литературе, али за разлику од претходне две Google Scholar користи све расположиве изворе научне литературе на интернету и служи за проналажење и бројање цитата. Зато што у томе користи све расположиве па и непроверене изворе не може бити реалан и валидан показатељ у цитатној анализи. Од времена настанка, 2004. године, ова база је много напредовала па се данас у цитатној анализи ослања и на специјално креиран софтвер за цитатну анализу под називом Publish or Perish (Harzing, A.W., 2007). Софтвер прикупља цитате и даје могућност цитатне анализе из WoS-a , Scopus-a, Google Scholar-a и приказује: укупан број радова, укупан број цитата, просек цитата по раду, цитата по аутору, број радова по аутору и цитата годишње, Хиршов һ-индекс и друге сродне параметре.

Европска листа часописа из хуманистичких и друштвених наука ERIH PLUS (European Reference Index for Humanities and Social Sciences), тренутно реферише седамдесет српских часописа и само два часописа Филолошког факултета (Славистиика и Кюиженстиво). Листа реферише часописе који испуњавају критеријуме за укључивање. ${ }^{13}$ Критеријуми поред техничких захтева за уређивање текстова,

10 SCImago Journal \& Country Rank [Portal] Доступно:

www.scimagojr.com [15.10.2020].

11 Pravilnik o postupku, načinu vrednovanaja i kvantitativnom iskazivanju (Sl. glasnik RS 24/2016 i 21/2017)

12 Исто, стр. 25.

13 ERIH PLUS criteria, Доступно: https:/dbh.nsd.uib.no/publiseringskanaler/ erihplus/about/criteria_for_inclusion [15.10.2020] 
Гордана Ј. Ђоковић

укључују и обавезан отворени приступ свим текстовима, било у форми потпуног отвореног приступа (Open Access) или путем DOI ознака које воде до пуног текста чланака.

\section{Закључак}

Цитираност научних резултата представља данас један од главних критеријума вредновања научног рада. Да би постигли већу цитираност, научни часописи морају постићи већу видљивост преко отвореног приступа и индексирања у цитатним базама података. Већа видљивост доноси већу прегледност објављених радова и на тај начин утиче и на повећање цитираности. Часописи који су категорисани или индексирани у некој од светских база или су категорисани у националним листама, видљивији су а самим тим радови објављени у њима се више цитирају. Такође, својом категоријом привлаче ауторе да објављују у њима. Захваљујући трајним идентификаторима DOI, приступ самој публикацији и њеним метаподацима је једноставнији jep се DOI лако трансформише у линк, увећава се број корисника који проналази жељене информације о публикацији, издавачи имају бољи увид у то ко и колико цитира њихове публикације, и што је најважније, сама цитираност се знатно увећава. Већа видљивост научних часописа, доследна уређивачка политика, DOI бројеви увећавају могућности за реферисање у угледним цитатним базама података (WoS и Scopus), што и јесте основни циљ свих издавача научне литературе у свету. 


\section{ЛИТЕРАТУРА}

1. Вранеш А., Марковић Љ. (2013). Og рукойиса gо библиоиекке - йојмовник. Београд: Филолошки факултет.

2. Шипка П. (2014). Методи вредновања научних часописа -употреба и злоупотреба. Моноїрафије научних скуйова АМН СЛД, 5 (1), 9-30

3. Macan B., Petrak J. (2015). Bibliometrijski pokazatelji za procjenu kvalitete znanstvenih časopisa. In I. Hebrang Grgić (ed), Hrvatski znanstveni časopisi (pp. 37-53). Zagreb: Školska knjiga.

\section{ИЗВОРИ}

1. Акт о уређивању научних часописа („Службени гласник Републике Србије“, бр 79/05)

2. Министраство просвете, науке и технолошког развоја/категоризација часописа . Доступно http://www.mpn.gov.rs/casopisi/ [приступ 22.9.2020.]

3. Bibliometrijski izveštaj o naučnim časopisima iz Republike Srbije http://bibliometrija.mi.sanu.ac.rs (приступ 23.9.2020.)

4. doi.Fil/Filološki fakultet, Univerzitet u Beogradu. Доступно преко http://doi.fil.bg.ac.rs [1.10.2020]

5. ERIH PLUS criteria, Доступно: https://dbh.nsd.uib.no/ publiseringskanaler/erihplus/about/criteria_for_inclusion [15.10.2020]

6. Harzing, A.W. (2007) Publish or Perish, Доступно:

https://harzing.com/resources/publish-or-perish [25.10.2020].

7. International Standard Serial Number. Доступно преко https://www.issn.org/ [3.10.2020]

8. Kobson/Referisani časopisi. Доступно: https://kobson.nb.rs/nauka_u_ srbiji/referisani_casopisi.23.html [3.10.2020].

9. Pravilnik o postupku, načinu vrednovanaja i kvantitativnom iskazivanju (Sl. glasnik RS 24/2016 i 21/2017)

10. SCImago Journal \& Country Rank [Portal] Доступно: www.scimagojr.com [15.10.2020]. 


\title{
Gordana Đoković
}

\section{SCIENTIFIC JOURNALS OF THE FACULTY OF PHILOLOGY: VISIBILITY, CITATION, EVALUATION}

\begin{abstract}
Summary
Scientific-research results and their quality are measured through the international visibility of scientific journals in which they are published. Higher visibility of scientific and research results leads to an increase in citations. Measurement of citation is one of the most important criteria in measuring the quality of scientists, magazines, faculties and universities. Inclusion in the most important and most prestigious electronic citation databases is an imperative for the editions of contemporary scientific journals. Faculty of Philology of the University of Belgrade has a very rich publishing production of scientific literature. The paper will give an overview of the titles of scientific journals published by the Faculty of Philology, measures that have led to increased visibility and analysis of their representation in electronic databases.
\end{abstract}

Key words: Faculty of Philology, University of Belgrade, scientific research results, visibility, citation, citation databases. 